\title{
Implications of circadian rhythm and stress in addiction
}

\section{vulnerability [version 1; peer review: 2 approved]}

\section{Darius Becker-Krail(iD, Colleen McClung}

School of Medicine, Department of Psychiatry, University of Pittsburgh, Pittsburgh, PA, USA

V1 First published: 13 Jan 2016, 5:59

https://doi.org/10.12688/f1000research.7608.1

Latest published: 13 Jan 2016, 5:59

https://doi.org/10.12688/f1000research.7608.1

\section{Abstract}

In the face of chronic stress, some individuals can maintain normal function while others go on to develop mental illness. Addiction, affecting one in every twelve people in America, is a substance use disorder long associated with stressful life events and disruptions in the sleep/wake cycle. The circadian and stress response systems have evolved to afford adaptability to environmental changes and allow for maintenance of functional stability, or homeostasis. This mini-review will discuss how circadian rhythms and stress individually affect drug response, affect each other, and how their interactions may regulate reward-related behavior. In particular, we will focus on the interactions between the circadian clock and the regulation of glucocorticoids by the hypothalamic-pituitary-adrenal (HPA) axis. Determining how these two systems act on dopaminergic reward circuitry may not only reveal the basis for vulnerability to addiction, but may also illuminate potential therapeutic targets for future investigation.

\section{Keywords}

Addiction, Circadian, Clock, Glucocorticoids, HPA, Reward, Stress, Vulnerability

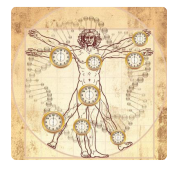

This article is included in the How clocks affect resilience in biological systems collection.

\author{
Open Peer Review \\ Approval Status \\ 1 \\ 2 \\ version 1 \\ 13 Jan 2016

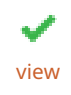 \\ $\checkmark$ \\ 1. Harry Pantazopoulos, McLean Hospital, \\ Belmont, USA \\ Syed Bukhari, McLean Hospital, Belmont, \\ USA \\ 2. Randy Nelson, Ohio State University College \\ of Medicine, Columbus, USA \\ Jeremy Borniger, Ohio State University \\ College of Medicine, Columbus, USA \\ Any reports and responses or comments on the \\ article can be found at the end of the article.
}


Corresponding author: Colleen McClung (McClungCA@upmc.edu)

Competing interests: No competing interests were disclosed.

Grant information: The author(s) declared that no grants were involved in supporting this work.

Copyright: $\odot 2016$ Becker-Krail D and McClung C. This is an open access article distributed under the terms of the Creative Commons Attribution License, which permits unrestricted use, distribution, and reproduction in any medium, provided the original work is properly cited.

How to cite this article: Becker-Krail D and McClung C. Implications of circadian rhythm and stress in addiction vulnerability

[version 1; peer review: 2 approved] F1000Research 2016, 5:59 https://doi.org/10.12688/f1000research.7608.1

First published: 13 Jan 2016, 5:59 https://doi.org/10.12688/f1000research.7608.1 


\section{Introduction}

Within any given environment, an organism must learn to anticipate and adapt to external changes/stressors in order to survive. Two systems, the circadian and stress response systems, have evolved to afford adaptability to both recurring and spontaneous environmental changes. Through the active process of allostasis (McEwen, 1998; Sterling \& Eyer, 1988), these systems and many others work to maintain an internal state of stability, or homeostasis, in the presence of these changes. In the face of acute and/or chronic stressors, the ability for an organism to adapt and avoid negative biological consequences is known as resilience. Within the context of psychopathology, resilience can be seen as a person's ability to maintain physiological and psychobiological homeostasis, in spite of adversity (Charney, 2004; Feder et al., 2009). While resilient individuals uphold "normal" mental health and homeostatic function when exposed to stress, other individuals may go on to develop neuropsychiatric or behavioral disorders. According to the vulnerability-stress model (Ingram \& Luxton, 2005; Zubin \& Spring, 1977), some individuals may be more biologically vulnerable to developing neuropsychiatric disorders when faced with acute and/or chronic stressors (Pihl \& Nantel-Vivier, 2005). To fully understand this phenomenon, current research seeks to understand the effects of stress in the brain (reviewed in McEwen et al., 2015), and elucidate potential structural and/or molecular bases resulting in the vulnerability to develop mental illnesses.

Many neuropsychiatric disorders have long been associated with altered circadian rhythm (Mills et al., 1977; Van Cauter \& Turek, 1986; Wehr et al., 1983) and stress response (Albus et al., 1982; Amsterdam et al., 1983; Roy et al., 1988); highlighted here, disruptions in both systems are also known to have implications in substance use disorder/addiction and reward-related behaviors (Briand \& Blendy, 2010; Falcón \& McClung, 2009; Koob, 2008; Logan et al., 2014). While abnormal circadian and stress response function can independently affect reward-related behavior, understanding the interface of these two systems, during both typical and atypical functioning, may provide greater insight into the complexities of disorder etiology. This mini-review examines the interplay of the circadian and stress response systems, and how this interaction may affect addiction vulnerability.

\section{Circadian rhythm and the molecular clock}

Highly conserved across most living organisms, circadian rhythms facilitate the anticipation and adaptation of behavior to daily changes in environmental stimuli. In mammalian organisms, system and cellular level rhythms are maintained by a rhythmgenerating nucleus in the hypothalamus, the suprachiasmatic nucleus (SCN). The SCN can be entrained by both photic and nonphotic cues called zeitgebers, or "time-keepers", but can ultimately generate a $\sim 24$ hour rhythm independent of these cues. At the molecular level, across all cell types, circadian rhythms are upheld by a "molecular clock" consisting of auto-regulatory transcriptiontranslation feedback loops in the nucleus (see Figure 1A). The key proteins that make up the molecular clock are transcription factors: circadian locomotor output cycles kaput (CLOCK), or neuronal PAS domain protein 2 (NPAS2), and brain and muscle Arnt-like protein 1 (BMAL1). Throughout the day, CLOCK/BMAL1 (or NPAS2/BMAL1) heterodimerize to promote the transcription of
Period (PER1,2,3), Cryptochrome (CRY1,2), and many other clock controlled genes (CCGs). The feedback loop is established when PER and CRY proteins accumulate in the cytoplasm, form heteroand homodimers, and eventually shuttle back into the nucleus to inhibit their own expression. Additionally, clock regulated RARrelated orphan receptor alpha $(\mathrm{ROR} \alpha)$ and reverse-ErbA alpha $(\mathrm{REV}-\mathrm{ERB} \alpha)$ nuclear receptors act in an auxiliary oscillatory feedback loop to regulate expression of Bmall, stabilizing the core feedback loop (Guillaumond et al., 2005). The circadian molecular clock cycles on a timescale of $\sim 24$ hours and regulates the expression of many genes controlling neuronal, metabolic, endocrine, and immune function (Jin et al., 1999; Lowrey \& Takahashi, 2000).

\section{Circadian genes and reward}

Several studies in the past two decades have shown core circadian genes to be important regulators of reward-related behavior in response to common substances of abuse, as reviewed by Parekh et al. (2015). One of the first studies investigating this link demonstrated that fruit flies with mutations in the Period, Clock, and/or Cycle (similar to Bmall in mammals) genes fail to show behavioral sensitization to cocaine (Andretic et al., 1999). In mice, mutations in the $m P e r 1$ and $m P e r 2$ genes seem to produce a similar but unique effect on cocaine response; mutation in $m P e r 2$ increased behavioral sensitization to cocaine but mutation in mPerl abolished sensitization (Abarca et al., 2002). Recently, our lab has been studying a similar differential regulation of reward, but with CLOCK and its functional homologue, NPAS2. While CLOCK is known to be expressed almost ubiquitously, NPAS2 is primarily expressed in the liver and forebrain (Bertolucci et al., 2008; Reick et al., 2001) and can regulate circadian transcription when CLOCK expression is absent or low. With notable implications for reward, NPAS2 has been shown to have a unique expression pattern in the mesolimbic pathway; NPAS2 is highly enriched in the nucleus accumbens (NAc), but has little to no expression in the ventral tegmental area (VTA) (Garcia et al., 2000).

The observation that NPAS2 is specifically enriched in the NAc motivated our most recent studies investigating the potential for CLOCK and NPAS2 to differentially regulate gene expression and reward-related behavior, following cocaine exposure. Interestingly, in response to chronic cocaine, only NPAS2 is upregulated in the NAc and caudate putamen (normal rhythm abolished) and has increased binding activity at Period gene promoters; CLOCK did not show these changes in the NAc or caudate putamen (Falcón et al., 2013). Knock-down of CLOCK or NPAS2 in these regions also has different effects on the regulation of reward-related behavior following cocaine administration. Mice containing a globally expressed, dominant negative, single-point mutation in the CLOCK protein $($ Clock $\Delta 19)$ exhibit a mania-like phenotype with increased baseline activity, decreased anxiety- and depression-like behavior, and increased sensitivity to rewarding stimuli; in response to cocaine, Clock $\Delta 19$ mice show increased conditioned place preference (CPP) and increased cocaine self-administration, relative to wild-type mice (McClung et al., 2005; Ozburn et al., 2012; Roybal et al., 2007). However, using AAV-shRNA to selectively knock-down CLOCK or NPAS2 in the NAc, near entire reduction of CLOCK in the NAc does not recapitulate increased preference seen in Clock $\Delta 19$; while mice with either a mutated form of 
A.

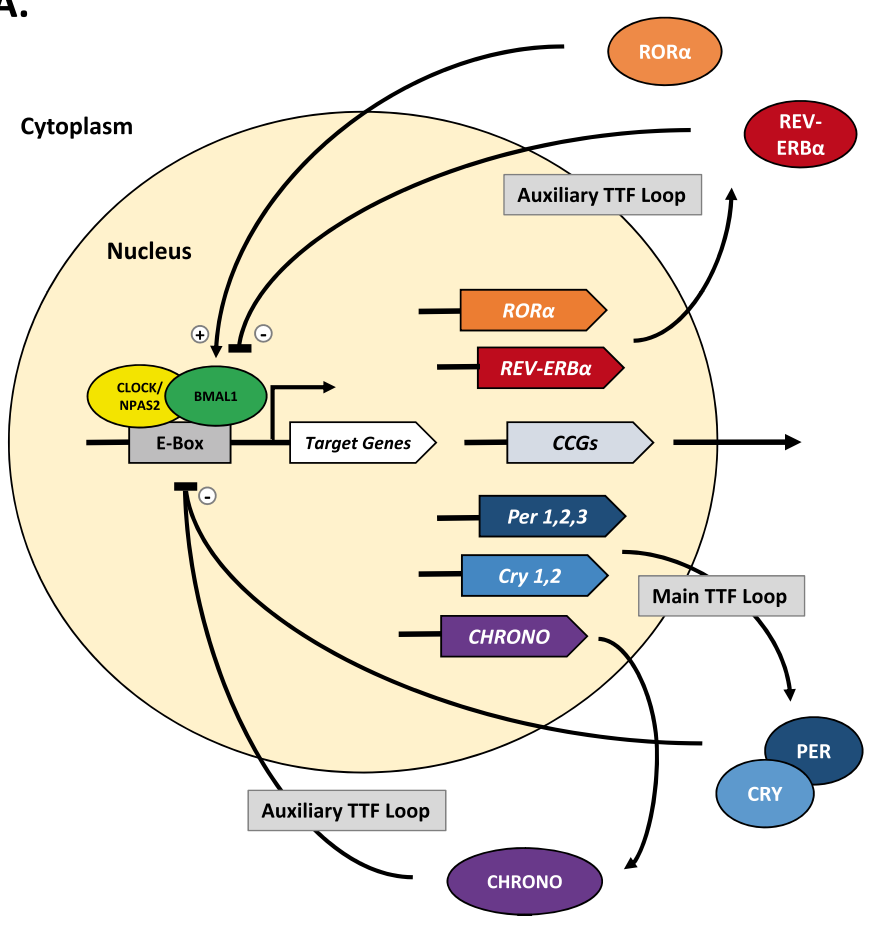

B.

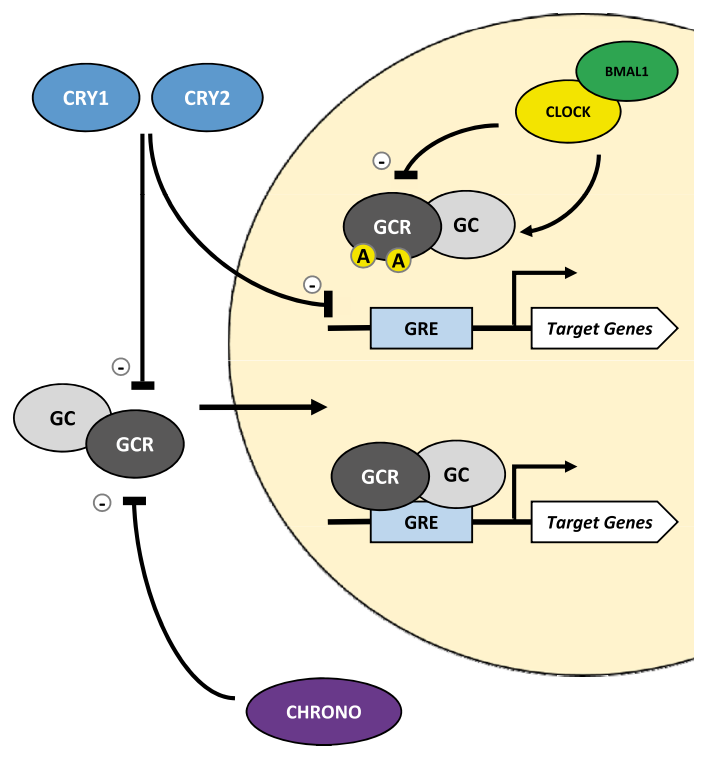

Figure 1. The circadian molecular clock and its interactions with the stress axis. A. The mammalian circadian molecular clock consists of multiple transcription and translation feedback (TTF) loops. Central to the TTF loops, the transcription factors CLOCK (or NPAS2) and BMAL1 heterodimerize and bind to the enhancer box (E-Box) sequence to promote transcription of many target and clock controlled genes (CCGs). The main TTF loop is achieved when PERIOD (PER1,2,3) and CRYPTOCHROME $(\mathrm{CRY} 1,2)$ proteins accumulate, dimerize, undergo phosphorylation, and shuttle back into the nucleus to inhibit both CLOCK/BMAL1 and, as a result, their own transcription. This negative feedback loop cycles every 24 hours and is crucial for regulation of circadian rhythm. Among its target genes, CLOCK/BMAL1 also regulates the expression of the nuclear receptors $R O R \alpha$ and $R E V$-ERB $\alpha$, both of which can regulate BMAL1 activity via binding at a response element in its promoter. A recently discovered circadian protein, CHRONO, is clock-regulated and can also inhibit CLOCK/BMAL1 activity via interactions at the E-Box. Taken together, these proteins make up auxiliary TTF loops that work to both stabilize and reinforce rhythm. B. The circadian molecular clock can interact with the stress axis through regulating activity of both glucocorticoid (GCC) and its receptor (GCR). GC is known to be released under tight circadian regulation, with peak levels in the animal's active phase. Additionally, several circadian proteins are known to rhythmically regulate GCR-dependent transcription activity. CLOCK/BMAL1 can directly attenuate GCR activity via acetylation (A), thereby reducing its binding ability at the Glucocorticoid Response Element (GRE). Simultaneously, CHRONO and CRY1,2 proteins can repress GCR activity via direct interaction in ligand-fashion. CRY proteins can also regulate GCR-dependent transcription through association at the GRE. (+), promote/activate; (-), repress/inhibit.

NPAS2 or a NAc specific knock-down of NPAS2 showed decreased cocaine CPP and self-administration (Ozburn et al., 2015).

The genes central to the circadian molecular clock may have differential roles in the regulation of reward-related behavior depending on the time of day, brain region, and/or the drug's effect on the specific protein in a particular region. Given the involvement of these core circadian genes in the regulation of reward and behavioral response, it is likely that disruption to the normal functioning/activity of these circadian proteins can contribute to the vulnerability of developing an addiction.

\section{HPA axis and reward}

When encountering physical and/or psychological stressors, activation of the hypothalamic-pituitary-adrenal (HPA) axis is a fundamental, evolutionarily conserved response allowing the organism to adapt both physiologically and behaviorally. Regulated by the HPA axis, glucocorticoids (cortisol in humans and corticosterone in rodents) are a class of steroid hormones responsible for driving the changes seen in stress response. Upon activation by limbic structures, neurons in the hypothalamic paraventricular nucleus (PVN) release corticotropin-releasing hormone $(\mathrm{CRH})$ at the median eminence into the hypophyseal portal system, connecting the 
hypothalamus with the anterior pituitary. Once stimulated by $\mathrm{CRH}$, the anterior pituitary increases secretion of adrenocorticotropic hormone (ACTH) into the bloodstream, where it will then travel to the adrenal gland. At the adrenal cortex, ACTH causes an increase in synthesis and release of glucocorticoids into the circulatory system to then act on energy metabolism, protein synthesis, immune function, cardiovascular function, attention/arousal/vigilance, and even memory function. Much like the circadian molecular clock, the HPA axis is regulated via a negative feedback loop in which accumulation of glucocorticoids in the hypothalamus (PVN) and anterior pituitary can block the production of CRH and ACTH. (de Kloet et al., 2005; Johnson et al., 1992; Uchoa et al., 2014).

While the effects of the HPA axis are transient in response to acute stress, chronic stress and prolonged presence of glucocorticoids can have deleterious outcomes, ranging from neurotoxicity and cell death to impaired metabolic/mitochondrial function and immunosuppression (de Kloet et al., 2005; Dhabhar \& McEwen, 1997; McEwen et al., 1999; Picard et al., 2014). Considering the potential detrimental effects of chronic stress, recent studies have investigated the implications of the HPA axis and glucocorticoids in neuropsychiatric disorder etiology (Herane Vives et al., 2015; Jacobson, 2014; Sapolsky, 2000; Yehuda et al., 2015). In the context of addiction, animal model studies have long demonstrated a strong association between chronic stress and increased behavioral response to drugs of abuse (Antelman et al., 1980; Deroche et al., 1995; Herman et al., 1984; MacLennan \& Maier, 1983). This increased response can be seen through augmented locomotor effects and increased reward/preference - both of which are associated with elevated glucocorticoid activity (Deroche et al., 1995; Haile et al., 2001; Lepsch et al., 2005). Further confirming the role of glucocorticoids in this phenomenon, if normal stress-induced increases in corticosterone (in rats) are blocked (via adrenalectomy), the stressrelated increase in drug behavioral response is abolished; notably, the response remains intact if normal elevation of corticosterone is artificially maintained (Deroche et al., 1995; Prasad et al., 1998; Rougé-Pont et al., 1995). Corticosterone has even been shown to be necessary for drug-induced sensitization in general, suggesting its importance in overall behavioral response and drug-seeking behavior, with or without stress as a factor (de Jong et al., 2009; Przegaliński et al., 2000).

Though it is clear that chronic stress and the biological mediators of stress response may alter one's sensitivity to the behavioral and/or rewarding effects of drugs of abuse, further investigation into the cellular and molecular bases of this relationship is necessary. Given that the circadian rhythm and stress response systems are both known to be involved in mediating behavioral responses to rewarding-substances, perhaps their interactions may be the key to understanding what drives vulnerability to addiction.

\section{Circadian regulation of the HPA axis}

Like many other processes in the body, the HPA axis and its hormonal components are under direct circadian regulation by both the SCN and a peripheral clock in the adrenal cortex (Ishida et al., 2005; Nader et al., 2010; Oster et al., 2006; Son et al., 2008). Glucocorticoids, along with the other hormones in the axis, display a prominent diurnal variation in which peak levels correspond with the organism's active phase (reviewed in: Kalsbeek et al., 2012; Spiga et al., 2014). Rhythms in glucocorticoids are not only mediated by both direct and indirect projections to the CRH producing PVN neurons at the fore-end of the HPA axis (Engeland \& Arhnhold, 2005; Kalsbeek et al., 2006), but also through modulation of receptors by core circadian proteins (See Figure 1B). Oster et al. (2006) demonstrated the importance of a functional adrenal molecular clock in "gating" sensitivity to ACTH (via ACTH receptors) in the adrenal cortex, as means of regulating glucocorticoid synthesis. Moreover, the actual glucocorticoid's effect across the body can also be regulated through acting on glucocorticoid receptor (GCR) function; multiple studies have demonstrated the ability for CLOCK/BMAL1 to modulate GCRs and their sensitivity via circadian mediated acetylation (Charmandari et al., 2011; Kino \& Chrousos, 2011; Nader et al., 2009). Alongside CLOCK/BMAL1, CRY1,2 have also been shown to repress GCR-dependent transcription activity via association with GCRs and/or at the glucocorticoid responsive element (GRE) (Lamia et al., 2011). In recent literature, a novel circadian protein named CHRONO, or computationally-highlighted/ChIP-derived repressor of network oscillator, acts as a negative regulator of the molecular clock and may even interact with GCRs to rhythmically repress their function (Anafi et al., 2014; Goriki et al., 2014). While investigation into CHRONO's function is still in its early stages, there is potential for this novel protein to play an even greater role in connecting the circadian and stress response systems.

Several circadian-gene mutant mouse studies have further verified the role of core molecular clock proteins in regulating the HPA axis. In Bmall null mutant mice, deficiency in BMAL1 causes a significant reduction in glucocorticoid levels, sensitivity, and altered rhythmicity (Leliavski et al., 2014); similarly, Clock mutant mice lacking functional CLOCK protein also show altered glucocorticoid rhythmicity and decreased total levels (Oishi et al., 2006; Takita et al., 2013). Along with the core CLOCK/BMAL1 complex, null mutations in the Cryptochrome (CRY1,2) or Period (PER1) genes also yield altered rhythmicity and, unlike Clock and Bmall mutants, increased total glucocorticoid levels (Dallmann et al., 2006; Destici et al., 2013; Lamia et al., 2011). Even more interesting, cultured BMAL1 and/or PER1,2 deficient mouse embryonic fibroblasts (MEFs) show altered GCR transactivation resulting in hypersensitivity to glucocorticoids (Han et al., 2014). Taken together, these studies demonstrate the importance of the molecular clock in regulating both the output of the stress axis and its efficacy.

\section{Stress effects on circadian rhythm}

Occurring simultaneously, the same components of the molecular clock that regulate HPA axis function can also be reciprocally affected by the stress itself. Most notably, chronic stress is known to affect the rhythmic expression of the core circadian genes. A key example can be found through glucocorticoids mediating the expression of Period genes. With either acute or chronic stress, levels of mPerl and PER1 are elevated in some neural and peripheral tissues (Al-Safadi et al., 2014; Al-Safadi et al., 2015; Takahashi et al., 2013). PER2 has a similar response to stress (Segall \& Amir, 2010; So et al., 2009) and even loses rhythmic expression in the bed nucleus of the stria terminalis (BNST) and in the amygdala, following adrenalectomy (Lamont et al., 2005). Additionally, 
it was later revealed that PER2 actually requires functional GCRs for its rhythmic expression (Segall et al., 2009). Both Period genes are afforded this unique relationship with glucocorticoids due to the presence of GREs in their promotor regions (So et al., 2009; Yamamoto et al., 2005). Glucocorticoids can target genes that have these GREs, bind, and thus promote their expression. This stressinduced change in gene expression, if occurring chronically, can even result in clock entrainment (Tahara et al., 2015).

Previous work in our lab has shown that mice exposed to chronic social defeat stress show increased anxiety that correlates with decreased $m P e r l / 2$ expression in the NAc (Spencer et al., 2012). While this may appear to conflict with aforementioned stress effects on Period genes, it is likely that region specific changes occur depending on the type of stressor, GCR distribution, and region/network involvement. Illustrating this, we recently showed mice subjected to the unpredictable chronic mild stress (UCMS) paradigm (used to model depression-like behavior) have increased Per2 rhythm amplitude in the NAc, but decreased rhythm amplitude in the SCN (Logan et al., 2015). This is likely due to GCR concentration being high in the NAc (Barik et al., 2010; Der-Avakian et al., 2006) but low/absent in the SCN (Balsalobre et al., 2000; Pezuk et al., 2012; Rosenfeld et al., 1988). The interaction between stress response and the circadian molecular clock in a region specific manner may perhaps be the basis that allows for manifestation of disorder specific vulnerability.

\section{Circadian rhythm and stress interactions in dopaminergic transmission}

As described above, a lot can be understood by just examining how each system not only affects each other, but also how they individually affect behavioral response to drugs of abuse. However, in the framework of addiction and reward, the effects on vulnerability may more likely arise from the two systems' interactions while simultaneously regulating the same reward-related processes. Both systems have been show to directly regulate/affect the dopaminergic reward circuitry and its functions involved in addiction (reviewed in: Marinelli \& Piazza, 2003; Parekh et al., 2014). Implemented in addiction, the mesolimbic pathway is a system of dopaminergic neurons connecting the VTA to the NAc, and is important for mediating reward-related behavior. This pathway's activity is known to be directly affected by both the circadian system and the stress response system (McClung et al., 2007; Trainor, 2011). In controlling dopamine synthesis, circadian molecular clock proteins and glucocorticoids may be working in opposing fashion to regulate expression of tyrosine hydroxylase (TH), a key enzyme in synthesis of dopamine from tyrosine (see Figure 2).

Under circadian control, recent work in our lab has demonstrated that CLOCK/BMAL1 acts as a time-dependent, negative regulator of $T H$ transcription via binding at the $T H$ promotor in anti-phase with CREB (Sidor et al., 2015). Opposite of CLOCK/BMAL1, glucocorticoids may positively regulate the expression and

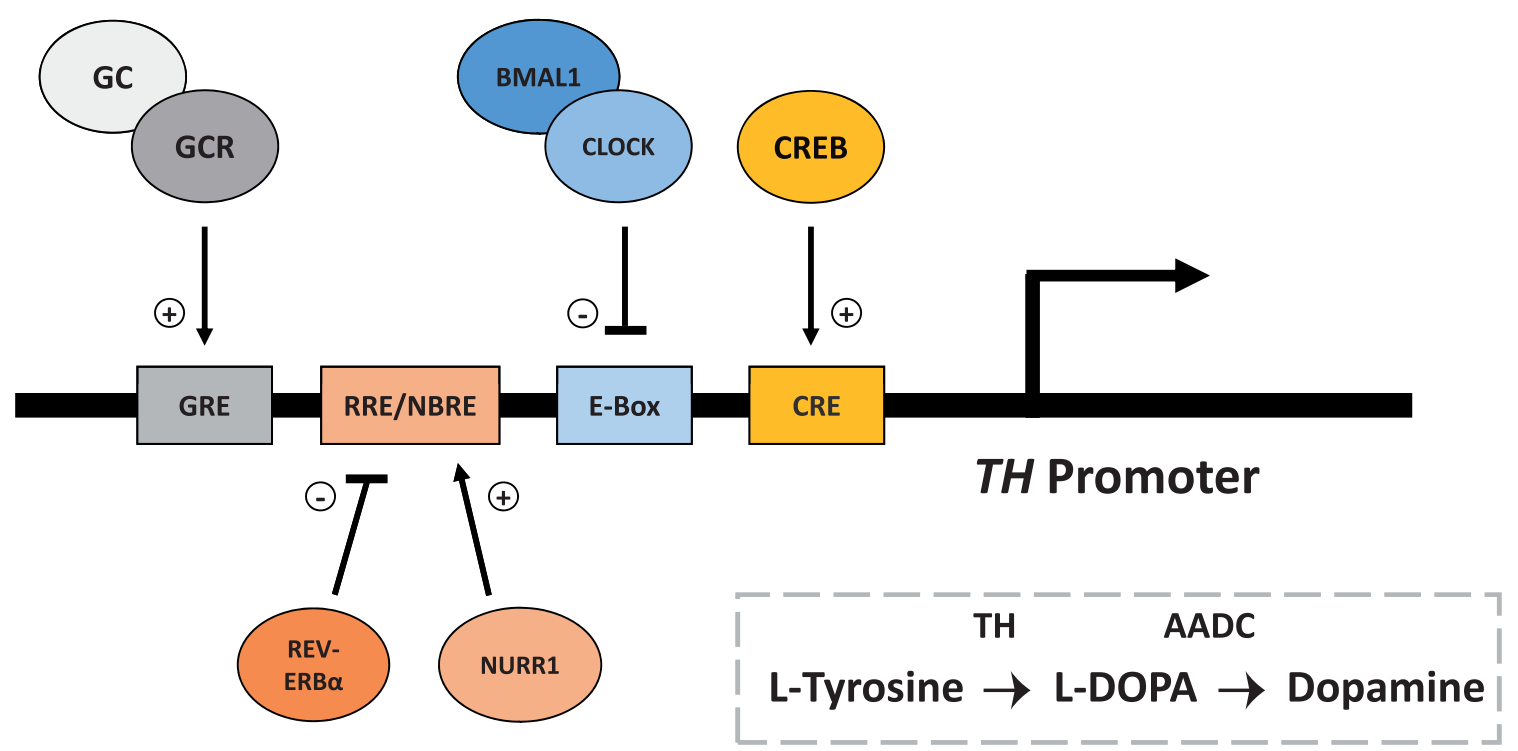

Figure 2. Dynamic circadian and stress interactions at the TH promoter. Important for reward-related behavior, tyrosine hydroxylase $(\mathrm{TH})$ is an enzyme involved in the synthesis of dopamine from the amino acid L-Tyrosine. Transcription of TH is mediated by the binding of cAMP response element-binding protein (CREB) at its response element (CRE) in the TH promoter. Dopamine synthesis is known to be directly regulated by both circadian and stress-related proteins/hormones. At the TH promoter, the core circadian CLOCK/BMAL1 complex binds to the enhancer-box (E-Box) sequence in antiphase with CREB:CRE binding, and negatively regulates the transcription of $T H$ in a time dependent manner. Additionally, the circadian nuclear receptor REV-ERB $\alpha$ and nuclear receptor-related 1 (NURR1) protein regulate TH expression via competitive binding at the REV-ERB/ROR response element (RRE)/NGF1B-response element (NBRE); while NURR1 promotes the expression of TH, REV-ERB $\alpha$ represses expression. Glucocorticoids (GCs) and its receptor (GCR) can also promote expression of TH by binding at the glucocorticoid response element (GRE) in the TH promoter. The above response element spacing is not shown to scale. (+), promote/activate; (-), repress/inhibit. 
activity of TH (Fossom et al., 1992; Kalinina et al., 2012; Núñez et al., 2009; Tank et al., 1986). While the exact mechanism by which glucocorticoids increase TH expression is still being investigated, it has been shown that the $T H$ promotor contains a GRE to which glucocorticoids can bind and promote expression independent of CRE (Hagerty et al., 2001a; Hagerty et al., 2001b). An additional explanation may arise through glucocorticoid regulation of the circadian nuclear receptor, REV-ERB $\alpha$. In a recent paper by Chung et al. (2014), REV-ERB $\alpha$ has been shown to repress $T H$ transcription through competitive binding with nuclear receptor-related 1 protein (NURR1) at the $T H$ promotor. Given that glucocorticoids have been shown to control REV-ERB $\alpha$ expression in the liver (Torra et al., 2000), it may be possible for glucocorticoids to increase TH through a disinhibition type mechanism.

In addition to regulation of $\mathrm{TH}$, the two systems can simultaneously act on dopamine receptor (DR) expression/function (Biron et al., 1992; Iasevoli et al., 2013; Ikeda et al., 2013; Spencer et al., 2012) and monoamine oxidase-A (MAO-A) expression/function, an enzyme responsible for degradation of dopamine (Chevillard et al., 1981; Cvijić et al., 1995; Hampp et al., 2008; Soliman et al., 2012). Taken together, these studies demonstrate the interactions of both the circadian system and stress response system in regulating the same aspects of reward related function/behavior. With slight disruption in either of the systems, the negative effects of one can alter the other and result in a self-perpetuating consequence. It is at this level that an understanding of vulnerability to addiction can be more readily obtained.

\section{Conclusion}

Reward-related behavior and sensitivity to drug response have both been shown to be regulated by the circadian and stress response systems. Described above, disruption in either of the systems individually can have pronounced effects on the rewarding effects of substances of abuse. Understanding both the tight circadian regulation of the stress axis and how stress/response can affect the molecular clock, the possibility for their interaction to drive vulnerability to addiction is entirely plausible. Both systems act in parallel regulating many aspects of reward related behavior and function. Slight mutations in either system causing minor functional disruption may be innocuous alone, but given the interface of the two systems, a minor change has the potential to be amplified in a reverberating fashion. The once subtle change may even become deleterious with time. It is in this logic that vulnerability to addiction is rooted; as a biological predisposition that becomes exploited in the face of chronic stressors. As an outlook, future studies can begin to consider one or both systems as potential therapeutic targets to mediate drug response in addiction and combat vulnerability.

\section{Author contributions}

DDBK prepared the manuscript. DDBK and CAM contributed equally to the revision of the draft manuscript and have agreed to the final content.

\section{Competing interests}

No competing interests were disclosed.

\section{Grant information}

The author(s) declared that no grants were involved in supporting this work.
Abarca $\mathrm{C}$, Albrecht $\mathrm{U}$, Spanagel $\mathrm{R}$ : Cocaine sensitization and reward are under the influence of circadian genes and rhythm. Proc Natl Acad Sci U S A. 2002; 99(13): 9026-30

PubMed Abstract | Publisher Full Text | Free Full Text

Albus M, Ackenheil M, Engel RR, et al:: Situational reactivity of autonomic functions in schizophrenic patients. Psychiatry Res. 1982; 6(3): 361-70. PubMed Abstract | Publisher Full Text

Al-Safadi S, Al-Safadi A, Branchaud M, et al.: Stress-induced changes in the expression of the clock protein PERIOD1 in the rat limbic forebrain and hypothalamus: role of stress type, time of day, and predictability. PLOS One. 2014; 9(10): e111166.

PubMed Abstract | Publisher Full Text | Free Full Text

Al-Safadi S, Branchaud M, Rutherford S, et al:: Glucocorticoids and StressInduced Changes in the Expression of PERIOD1 in the Rat Forebrain. PLoS One. 2015; 10(6): e0130085.

PubMed Abstract | Publisher Full Text | Free Full Text

Amsterdam JD, Winokur A, Lucki I, et al.: A neuroendocrine test battery in bipolar patients and healthy subjects. Arch Gen Psychiatry. 1983; 40(5): 515-21. PubMed Abstract | Publisher Full Text

Anafi RC, Lee Y, Sato TK, et al:: Machine learning helps identify CHRONO as a circadian clock component. PLoS Biol. 2014; 12(4): e1001840. PubMed Abstract | Publisher Full Text | Free Full Text

Andretic R, Chaney S, Hirsh J: Requirement of circadian genes for cocaine sensitization in Drosophila. Science. 1999; 285(5430): 1066-8.

PubMed Abstract | Publisher Full Text

Antelman SM, Eichler AJ, Black CA, et al.: Interchangeability of stress and amphetamine in sensitization. Science. 1980; 207(4428): 329-331. PubMed Abstract | Publisher Full Text

Balsalobre A, Brown SA, Marcacci L, et al.: Resetting of circadian time in peripheral tissues by glucocorticoid signaling. Science. 2000; 289(5488) 2344-2347.

PubMed Abstract | Publisher Full Text

Barik J, Parnaudeau S, Saint Amaux AL, et al:: Glucocorticoid receptors in dopaminoceptive neurons, key for cocaine, are dispensable for molecular and behavioral morphine responses. Biol Psychiatry. 2010; 68(3): 231-9. PubMed Abstract | Publisher Full Text

Bertolucci C, Cavallari N, Colognesi I, et al:: Evidence for an overlapping role of CLOCK and NPAS2 transcription factors in liver circadian oscillators. Mol Cell Biol. 2008; 28(9): 3070-5.

PubMed Abstract | Publisher Full Text | Free Full Text

Biron D, Dauphin C, Di Paolo T: Effects of adrenalectomy and glucocorticoids on rat brain dopamine receptors. Neuroendocrinology. 1992; 55(4): 468-76. PubMed Abstract | Publisher Full Text

Briand LA, Blendy JA: Molecular and genetic substrates linking stress and addiction. Brain Res. 2010; 1314: 219-34. PubMed Abstract | Publisher Full Text | Free Full Text Charmandari E, Chrousos GP, Lambrou GI, et al:: Peripheral CLOCK regulates target-tissue glucocorticoid receptor transcriptional activity in a circadian target-tissue glucocorticoid receptor transcription
fashion in man. PLoS One. 2011; 6(9): e25612. fashion in man. PLoS One. 2011; 6(9): e25612.
PubMed Abstract | Publisher Full Text | Free Full Text Charney DS: Psychobiological mechanisms of resilience and vulnerability: implications for successful adaptation to extreme stress. Am J Psychiatry. 
2004; 161(2): 195-216.

PubMed Abstract | Publisher Full Text

Chevillard C, Barden N, Saavedra JM: Twenty-four hour rhythm in monoamine oxidase activity in specific areas of the rat brain stem. Brain Res. 1981; 223(1) 205-9.

PubMed Abstract | Publisher Full Text

Chung S, Lee EJ, Yun S, et al.: Impact of circadian nuclear receptor REV-ERB on midbrain dopamine production and mood regulation. Cell. 2014; 157(4): $858-68$.

PubMed Abstract | Publisher Full Text

Cvijić G, Radojicić R, Djordjević J, et al.: The effect of glucocorticoids on the activity of monoamine oxidase, copper-zinc superoxide dismutase and catalase in the rat hypothalamus. Funct Neurol. 1995; 10(4-5): 175-81. PubMed Abstract

Dallmann R, Touma C, Palme R, et al:: Impaired daily glucocorticoid rhythm in Per1 ${ }^{\text {Brd }}$ mice. J Comp Physiol A Neuroethol Sens Neural Behav Physiol. 2006; 192(7): 769-775.

PubMed Abstract | Publisher Full Tex

de Jong IE, Steenbergen PJ, de Kloet ER: Behavioral sensitization to cocaine: cotion (Berl.). 2009; 204(4): 693-703.

PubMed Abstract | Publisher Full Text | Free Full Text

de Kloet ER, Joëls M, Holsboer F: Stress and the brain: from adaptation to disease. Nat Rev Neurosci. 2005; 6(6): 463-75.

PubMed Abstract | Publisher Full Text

Der-Avakian A, Bland ST, Schmid MJ, et al:: The role of glucocorticoids in the uncontrollable stress-induced potentiation of nucleus accumbens shell dopamine and conditioned place preference responses to morphine.

Psychoneuroendocrinology. 2006; 31(5): 653-663.

PubMed Abstract | Publisher Full Text

Deroche V, Marinelli M, Maccari S, et al:: Stress-induced sensitization and glucocorticoids. I. Sensitization of dopamine-dependent locomotor effects of amphetamine and morphine depends on stress-induced corticosterone secretion. J Neurosci. 1995; 15(11): 7181-8.

PubMed Abstract

Destici E, Jacobs EH, Tamanini F, et al:: Altered phase-relationship between peripheral oscillators and environmental time in Cry1 or Cry2 deficient mouse models for early and late chronotypes. PLoS One. 2013; 8(12): e83602. PubMed Abstract | Publisher Full Text | Free Full Text

Dhabhar FS, McEwen BS: Acute stress enhances while chronic stress suppresses cell-mediated immunity in vivo: a potential role for leukocyte trafficking. Brain Behav Immun. 1997; 11(4): 286-306.

PubMed Abstract | Publisher Full Tex

Engeland WC, Arnhold MM: Neural circuitry in the regulation of adrenal corticosterone rhythmicity. Endocrine. 2005; 28(3): 325-32.

PubMed Abstract | Publisher Full Text

Falcón E, McClung CA: A role for the circadian genes in drug addiction. Neuropharmacology. 2009; 56(Suppl 1): 91-6.

PubMed Abstract | Publisher Full Text | Free Full Text

Falcón E, Ozburn A, Mukherjee $S$, et al: Differential regulation of the period genes in striatal regions following cocaine exposure. PLoS One. 2013; 8(6): e66438.

PubMed Abstract | Publisher Full Text | Free Full Text

Feder A, Nestler EJ, Charney DS: Psychobiology and molecular genetics of resilience. Nat Rev Neurosci. 2009; 10(6): 446-57.

PubMed Abstract | Publisher Full Text | Free Full Text

Fossom LH, Sterling CR, Tank AW: Regulation of tyrosine hydroxylase gene transcription rate and tyrosine hydroxylase mRNA stability by cyclic AMP and glucocorticoid. Mol Pharmacol. 1992; 42(5): 898-908.

PubMed Abstract

Garcia JA, Zhang D, Estill SJ, et al.: Impaired cued and contextual memory in NPAS2-deficient mice. Science. 2000; 288(5474): 2226-30.

PubMed Abstract | Publisher Full Text

Goriki A, Hatanaka F, Myung J, et al.: A novel protein, CHRONO, functions as a core component of the mammalian circadian clock. PLOS Biol. 2014; 12(4) e1001839.

PubMed Abstract | Publisher Full Text | Free Full Text

Guillaumond F, Dardente H, Giguère V, et al.: Differential control of Bmal1 circadian transcription by REV-ERB and ROR nuclear receptors. J Biol Rhythms. 2005; 20(5): 391-403.

PubMed Abstract | Publisher Full Text

Hagerty T, Fernandez E, Lynch K, et al.: Interaction of a glucocorticoidresponsive element with regulatory sequences in the promoter region of the mouse tyrosine hydroxylase gene. J Neurochem. 2001b; 78(6): 1379-88. PubMed Abstract | Publisher Full Text

Hagerty T, Morgan WW, Elango N, et al.: Identification of a glucocorticoidresponsive element in the promoter region of the mouse tyrosine hydroxylase gene. J. Neurochem. 2001a; 76(3): 825-34.

PubMed Abstract | Publisher Full Tex

Haile CN, GrandPre T, Kosten TA: Chronic unpredictable stress, but not chronic predictable stress, enhances the sensitivity to the behavioral effects of cocaine in rats. Psychopharmacology (Berl). 2001; 154(2): 213-20.

PubMed Abstract | Publisher Full Text
Hampp G, Ripperger JA, Houben T, et al:: Regulation of monoamine oxidase A by circadian-clock components implies clock influence on mood. Curr Biol. 2008; 18(9): 678-83.

PubMed Abstract | Publisher Full Text

Han DH, Lee YJ, Kim K, et al.: Modulation of glucocorticoid receptor induction properties by core circadian clock proteins. Mol Cell Endocrinol. 2014; 383(1-2): $170-80$

PubMed Abstract | Publisher Full Text

Herane Vives A, De Angel V, Papadopoulos A, et al:: The relationship between cortisol, stress and psychiatric illness: New insights using hair analysis.

J Psychiatr Res. 2015; 70: 38-49.

PubMed Abstract | Publisher Full Text

Herman JP, Stinus L, Le Moal M: Repeated stress increases locomotor response to amphetamine. Psychopharmacology (Berl). 1984; 84(3): 431-435. PubMed Abstract | Publisher Full Text

lasevoli F, Aloj L, Latte G, et al:: The glucocorticoid analog dexamethasone alters the expression and the distribution of dopamine receptors and enkephalin within cortico-subcortical regions. Curr Mol Pharmacol. 2013; 6(3): 149-55.

PubMed Abstract | Publisher Full Text

Ikeda $\mathrm{E}$, Matsunaga N, Kakimoto $\mathrm{K}$, et al:: Molecular mechanism regulating

24-hour rhythm of dopamine D3 receptor expression in mouse ventral

striatum. Mol Pharmacol. 2013; 83(5): 959-967.

PubMed Abstract | Publisher Full Text

Ingram RE, Luxton DD: Vulnerability-Stress Models. in Development of

Psychopathology: A Vulnerability-Stress Perspective. eds BL Hankin, JRZ Abela.

(California: Sage Publications, Inc.). 2005; 32-46.

Publisher Full Text

Ishida A, Mutoh T, Ueyama T, et al: Light activates the adrenal gland: timing of gene expression and glucocorticoid release. Cell Metab. 2005; 2(5): 297-307.

PubMed Abstract | Publisher Full Text

Jacobson L: Hypothalamic-pituitary-adrenocortical axis: neuropsychiatric aspects. Compr Physiol. 2014; 4(2): 715-38.

PubMed Abstract | Publisher Full Text

Jin X, Shearman LP, Weaver DR, et al:: A molecular mechanism regulating rhythmic output from the suprachiasmatic circadian clock. Cell. 1999; 96(1) 57-68.

PubMed Abstract | Publisher Full Text

Johnson EO, Kamilaris TC, Chrousos GP, et al:: Mechanisms of stress: a dynamic overview of hormonal and behavioral homeostasis. Neurosci Biobehav Rev. 1992; 16(2): 115-30.

PubMed Abstract | Publisher Full Text

Kalinina TS, Shishkina GT, Dygalo NN: Induction of tyrosine hydroxylase gene expression by glucocorticoids in the perinatal rat brain is age-dependent.

Neurochem Res. 2012; 37(4): 811-8.

PubMed Abstract | Publisher Full Text

Kalsbeek A, Palm IF, La Fleur SE, et al:: SCN outputs and the hypothalamic balance of life. J Biol Rhythms. 2006; 21(6): 458-69.

PubMed Abstract | Publisher Full Text

Kalsbeek A, van der Spek R, Lei J, et al.: Circadian rhythms in the hypothalamopituitary-adrenal (HPA) axis. Mol Cell Endocrinol. 2012; 349(1): 20-9.

PubMed Abstract | Publisher Full Text

Kino T, Chrousos GP: Acetylation-mediated epigenetic regulation of glucocorticoid receptor activity: circadian rhythm-associated alterations of glucocorticoid actions in target tissues. Mol Cell Endocrinol. 2011; 336(1-2):

$23-30$.

PubMed Abstract | Publisher Full Text | Free Full Text

Koob GF: A role for brain stress systems in addiction. Neuron. 2008; 59(1):

11-34.

PubMed Abstract | Publisher Full Text | Free Full Text

Lamia KA, Papp SJ, Yu RT, et al.: Cryptochromes mediate rhythmic repression of the glucocorticoid receptor. Nature. 2011; 480(7378): 552-6.

PubMed Abstract | Publisher Full Text | Free Full Text

Lamont EW, Robinson B, Stewart J, et al:: The central and basolateral nuclei of the amygdala exhibit opposite diurnal rhythms of expression of the clock protein Period2. Proc Natl Acad Sci U S A. 2005; 102(11): 4180-4.

PubMed Abstract | Publisher Full Text | Free Full Text

Leliavski A, Shostak A, Husse J, et al.: Impaired glucocorticoid production and response to stress in Arntl-deficient male mice. Endocrinology. 2014; 155(1): 133-42.

PubMed Abstract | Publisher Full Text

Logan RW, Edgar N, Gillman AG, et al.: Chronic Stress Induces Brain RegionSpecific Alterations of Molecular Rhythms that Correlate with Depression-like Behavior in Mice. Biol Psychiatry. 2015; 78(4): 249-258.

PubMed Abstract | Publisher Full Text | Free Full Text

Logan RW, Williams WP 3rd, McClung CA: Circadian rhythms and addiction: mechanistic insights and future directions. Behav Neurosci. 2014; 128(3): 387-412.

PubMed Abstract | Publisher Full Text | Free Full Text

Lowrey PL, Takahashi JS: Genetics of the mammalian circadian system:

Photic entrainment, circadian pacemaker mechanisms, and posttranslational regulation. Annu Rev Genet. 2000; 34: 533-562.

PubMed Abstract | Publisher Full Tex 
MacLennan AJ, Maier SF: Coping and the stress-induced potentiation of stimulant stereotypy in the rat. Science. 1983; 219(4588): 1091-1093. PubMed Abstract | Publisher Full Text

Marinelli M, Piazza PV: Influence of Environmental and Hormonal Factors in Sensitivity to Psychostimulants. in Molecular Biology of Drug Addiction, ed R Maldonado (New York: Springer Science + Business Media, LLC): 2003; 133-159. Reference Source

McClung CA, Sidiropoulou K, Vitaterna M, et al.: Regulation of dopaminergic transmission and cocaine reward by the Clock gene. Proc Natl Acad Sci U S A. 2005; 102(26): 9377-81

PubMed Abstract | Publisher Full Text | Free Full Text

McClung CA: Circadian rhythms, the mesolimbic dopaminergic circuit, and drug addiction. ScientificWorldJournal. 2007; 7(S2): 194-202.

PubMed Abstract | Publisher Full Text

McEwen BS, Bowles NP, Gray JD, et al.: Mechanisms of stress in the brain. Nat Neurosci. 2015; 18(10): 1353-63.

PubMed Abstract | Publisher Full Text

McEwen BS, de Leon MJ, Lupien SJ, et al.: Corticosteroids, the Aging Brain and Cognition. Trends Endocrinol Metab. 1999; 10(3): 92-96.

PubMed Abstract | Publisher Full Text

McEwen BS: Stress, adaptation, and disease. Allostasis and allostatic load. Ann N Y Acad Sci. 1998; 840: 33-44.

PubMed Abstract | Publisher Full Text

Mills JN, Morgan R, Minors DS, et al:: The free-running circadian rhythms of two schizophrenics. Chronobiologia. 1977; 4(4): 353-360.

PubMed Abstract

Nader N, Chrousos GP, Kino T: Circadian rhythm transcription factor CLOCK regulates the transcriptional activity of the glucocorticoid receptor by acetylating its hinge region lysine cluster: potential physiological implications. FASEB J. 2009; 23(5): 1572-83.

PubMed Abstract | Publisher Full Text | Free Full Text

Nader N, Chrousos GP, Kino T: Interactions of the circadian CLOCK system and the HPA axis. Trends Endocrinol Metab. 2010; 21(5): 277-86.

PubMed Abstract | Publisher Full Text | Free Full Text

Núñez C, Földes A, Pérez-Flores D, et al:: Elevated glucocorticoid levels are responsible for induction of tyrosine hydroxylase mRNA expression, phosphorylation, and enzyme activity in the nucleus of the solitary tract during morphine withdrawal. Endocrinology. 2009; 150(7): 3118-27. PubMed Abstract | Publisher Full Text | Free Full Text

Oishi K, Ohkura N, Kadota K, et al.: Clock mutation affects circadian regulation of circulating blood cells. J Circadian Rhythms. 2006; 4: 13.

PubMed Abstract | Free Full Text

Oster H, Damerow S, Kiessling S, et al.: The circadian rhythm of glucocorticoids is regulated by a gating mechanism residing in the adrenal cortical clock. Cell Metab. 2006; 4(2): 163-73.

PubMed Abstract | Publisher Full Text

Ozburn AR, Falcon E, Twaddle A, et al.: Direct regulation of diurnal Drd3 expression and cocaine reward by NPAS2. Biol Psychiatry. 2015; 77(5): 425-33. PubMed Abstract | Publisher Full Text | Free Full Text

Ozburn AR, Larson EB, Self DW, et al:: Cocaine self-administration behaviors in Clocks19 mice. Psychopharmacology (Berl). 2012; 223(2): 169-77.

PubMed Abstract | Publisher Full Text | Free Full Text

Parekh PK, Ozburn AR, McClung CA: Circadian clock genes: effects on dopamine, reward and addiction. Alcohol. 2015; 49(4): 341-9.

PubMed Abstract | Publisher Full Text

Pezük P, Mohawk JA, Wang LA, et al.: Glucocorticoids as entraining signals for peripheral circadian oscillators. Endocrinology. 2012; 153(10): 4775-83. PubMed Abstract | Publisher Full Text | Free Full Text

Picard M, Juster RP, McEwen BS: Mitochondrial allostatic load puts the 'gluc' back in glucocorticoids. Nat Rev Endocrinol. 2014; 10(5): 303-10.

PubMed Abstract | Publisher Full Tex

Pihl RO, Nantel-Vivier A: Biological Vulnerabilities to the Development of Psychopathology. In Development of Psychopathology: A Vulnerability-Stress Perspective. eds B.L. Hankin and J.R.Z. Abela (California: Sage Publications, Inc.), 2005; 75-103.

Publisher Full Text

Prasad BM, Ulibarri C, Sorg BA: Stress-induced cross-sensitization to cocaine: effect of adrenalectomy and corticosterone after short- and long-term withdrawal. Psychopharmacology (Berl). 1998; 136(1): 24-33.

PubMed Abstract | Publisher Full Text

Przegaliński E, Filip M, Siwanowicz J, et al.: Effect of adrenalectomy and corticosterone on cocaine-induced sensitization in rats. $J$ Physiol Pharmacol. 2000; 51(2): 193-204.

PubMed Abstract

Reick M, Garcia JA, Dudley C, et al.: NPAS2: an analog of clock operative in the mammalian forebrain. Science. 2001; 293(5529): 506-9.

PubMed Abstract | Publisher Full Text

Rosenfeld P, Van Eekelen JA, Levine S, et al:: Ontogeny of the Type 2

glucocorticoid receptor in discrete rat brain regions: an immunocytochemica study. Brain Res. 1988; 470(1): 119-127.

PubMed Abstract | Publisher Full Text

Rougé-Pont F, Marinelli M, Le Moal M, et al: Stress-induced sensitization and glucocorticoids. II. Sensitization of the increase in extracellular dopamine induced by cocaine depends on stress-induced corticosterone secretion.
J Neurosci. 1995; 15(11): 7189-95

PubMed Abstract

Roy A, Pickar D, De Jong J, et al:: Norepinephrine and its metabolites in cerebrospinal fluid, plasma, and urine. Relationship to hypothalamic-pituitaryadrenal axis function in depression. Arch Gen Psychiatry. 1988; 45(9): 849-57. PubMed Abstract | Publisher Full Text

Roybal K, Theobold D, Graham A, et al.: Mania-like behavior induced by disruption of CLOCK. Proc Natl Acad Sci USA. 2007; 104(15): 6406-11.

PubMed Abstract | Publisher Full Text | Free Full Text

Russo S, Murrough J, Han MH, et al.: Neurobiology of resilience. Nat Neurosci. 2012; 15(11): 1475-1484.

PubMed Abstract | Publisher Full Text | Free Full Text

Sapolsky RM: Glucocorticoids and hippocampal atrophy in neuropsychiatric disorders. Arch Gen Psychiatry. 2000; 57(10): 925-35.

PubMed Abstract | Publisher Full Text

Segall LA, Amir S: Exogenous corticosterone induces the expression of the clock protein, PERIOD2, in the oval nucleus of the bed nucleus of the stria terminalis and the central nucleus of the amygdala of adrenalectomized and intact rats. J Mol Neurosci. 2010; 42(2): 176-182.

PubMed Abstract | Publisher Full Text

Segall LA, Milet A, Tronche F, et al:: Brain glucocorticoid receptors are necessary for the rhythmic expression of the clock protein, PERIOD2, in the central extended amygdala in mice. Neurosci Lett. 2009; 457(1): 58-60.

PubMed Abstract | Publisher Full Text

So AY, Bernal TU, Pillsbury ML, et al:: Glucocorticoid regulation of the circadian clock modulates glucose homeostasis. Proc Natl Acad Sci U S A. 2009; 106(41): 17582-17587.

PubMed Abstract | Publisher Full Text | Free Full Text

Soliman A, Udemgba C, Fan I, et al.: Convergent effects of acute stress and glucocorticoid exposure upon MAO-A in humans. J Neurosci. 2012; 32(48): 17120-7. PubMed Abstract | Publisher Full Text

Son GH, Chung S, Choe HK, et al:: Adrenal peripheral clock controls the autonomous circadian rhythm of glucocorticoid by causing rhythmic steroid production. Proc Natl Acad Sci U S A. 2008; 105(52): 20970-5.

PubMed Abstract | Publisher Full Text | Free Full Text

Spencer S, Torres-Altoro MI, Falcon E, et al:: A mutation in CLOCK leads to altered dopamine receptor function. $J$ Neurochem. 2012; 123(1): 124-34. PubMed Abstract | Publisher Full Text | Free Full Text

Spiga F, Walker JJ, Terry JR, et al.: HPA axis-rhythms. Compr Physiol. 2014; 4(3): 1273-98.

PubMed Abstract | Publisher Full Text

Sterling P, Eyer J: Allostasis: a new paradigm to explain arousal pathology. In Handbook of Life Stress, Cognition and Health, eds., S Fisher and J Reason (New York: John Wiley \& Sons), 1988; 629-649.

Reference Source

Tahara Y, Shiraishi T, Kikuchi Y, et al.: Entrainment of the mouse circadian clock by sub-acute physical and psychological stress. Sci Rep. 2015; 5: 1-11. PubMed Abstract | Publisher Full Text | Free Full Text

Takahashi K, Yamada T, Tsukita S, et al:: Chronic mild stress alters circadian expressions of molecular clock genes in the liver. Am J Physiol Endocrinol Metab. 2013; 304(3): E301-E309.

PubMed Abstract | Publisher Full Text

Takita E, Yokota S, Tahara Y, et al.: Biological clock dysfunction exacerbates contact hypersensitivity in mice. Br J Dermatol. 2013; 168(1): 39-46.

PubMed Abstract | Publisher Full Text

Tank AW, Curella P, Ham L: Induction of mRNA for tyrosine hydroxylase by cyclic AMP and glucocorticoids in a rat pheochromocytoma cell line: evidence for the regulation of tyrosine hydroxylase synthesis by multiple mechanisms in cells exposed to elevated levels of both inducing agents. Mol Pharmacol. 1986; 30(5): 497-503.

PubMed Abstract

Torra IP, Tsibulsky V, Delaunay F, et al.: Circadian and glucocorticoid regulation of Rev-erbalpha expression in liver. Endocrinology. 2000; 141(10): 3799-806. PubMed Abstract | Publisher Full Text

Trainor BC: Stress responses and the mesolimbic dopamine system: social contexts and sex differences. Horm Behav. 2011; 60(5): 457-69.

PubMed Abstract | Publisher Full Text | Free Full Text

Uchoa ET, Aguilera G, Herman JP, et al:: Novel aspects of glucocorticoid

actions. J Neuroendocrinol. 2014; 26(9): 557-72.

PubMed Abstract | Publisher Full Text | Free Full Text

Van Cauter E, Turek FW: Depression: a disorder of timekeeping? Perspect Bio Med. 1986; 29(4): 510-519.

PubMed Abstract | Publisher Full Text

Wehr TA, Sack D, Rosenthal N, et al:: Circadian rhythm disturbances in manicdepressive illness. Fed Proc. 1983; 42(11): 2809-14.

PubMed Abstract

Yamamoto T, Nakahata Y, Tanaka M, et al.: Acute physical stress elevates mouse period 1 mRNA expression in mouse peripheral tissues via a glucocorticoid-responsive element. J Biol Chem. 2005; 280(51): 42036-43. PubMed Abstract | Publisher Full Text

Yehuda R, Flory JD, Bierer LM, et al:: Lower methylation of glucocorticoid receptor gene promoter $1_{E}$ in peripheral blood of veterans with posttraumatic stress disorder. Biol Psychiatry. 2015; 77(4): 356-64.

PubMed Abstract | Publisher Full Text 


\section{Open Peer Review}

\section{Current Peer Review Status:}

\section{Version 1}

Reviewer Report 02 February 2016

https://doi.org/10.5256/f1000research.8194.r11935

(C) 2016 Nelson R et al. This is an open access peer review report distributed under the terms of the Creative Commons Attribution License, which permits unrestricted use, distribution, and reproduction in any medium, provided the original work is properly cited.

\section{Randy Nelson}

Department of Neuroscience, Ohio State University College of Medicine, Columbus, OH, USA Jeremy Borniger

Department of Neuroscience, Ohio State University College of Medicine, Columbus, OH, USA

The authors provide an excellent and timely mini-review of the interactions between the circadian and stress response systems, and their actions on dopaminergic reward circuitry underlying addiction and diseases of drug abuse. They highlight the differential expression levels of BMAL1 binding partners CLOCK and NPAS2 throughout the brain, indicating that NPAS2 is specifically enriched in the nucleus accumbens. This sets the stage for the idea that selective manipulation of the circadian clock through NPAS2 in the nucleus accumbens could influence reward-seeking behavior. Additional evidence is discussed regarding the binding of CLOCK/BMAL1 at the tyrosine hydroxylase promoter to repress transcription and therefore dopamine synthesis.

The authors further discuss the fundamental link between the HPA axis and the circadian clock through glucocorticoid-response elements in clock gene and tyrosine hydroxylase promoters, acetylation of the glucocorticoid receptor by CLOCK/BMAL1, and other potential interactions with the newly discovered clock component CHRONO. The review is concise and provides an excellent starting point for anyone interested in the etiology, treatment, or molecular biology of addiction or drug abuse.

It may be beyond the scope of this review, but future discussion of the effects drugs of abuse on the circadian clock may be warranted.

Is there any evidence for circadian control of opioid reward signaling? It may be worth discussing stress effects on opioid or opioid-receptor expression in the VTA or NAc on a circadian basis. (e.g., Polter et al, 2014, Biological Psychiatry Vol 76: 785-793).

Competing Interests: No competing interests were disclosed.

We confirm that we have read this submission and believe that we have an appropriate level of expertise to confirm that it is of an acceptable scientific standard. 
Reviewer Report 01 February 2016

https://doi.org/10.5256/f1000research.8194.r12056

(C) 2016 Pantazopoulos $\mathbf{H}$ et al. This is an open access peer review report distributed under the terms of the Creative Commons Attribution License, which permits unrestricted use, distribution, and reproduction in any medium, provided the original work is properly cited.

\section{Harry Pantazopoulos}

Translational Neuroscience Laboratory, McLean Hospital, Belmont, MA, USA

\section{Syed Bukhari}

Translational Neuroscience Laboratory, McLean Hospital, Belmont, MA, USA

This is a well written and timely summary of interactions between the circadian system and the stress response system set in the framework of drug addiction/reward. The article provides an accurate summary of the current literature and a helpful introduction of these biological systems to readers who are unfamiliar with the field. The figures are clear, well-described, and aid the reader in understanding the molecular mechanisms described in the text. In addition, the evolution/environmental interaction perspective in the introduction provides an excellent framework for the following discussion of how interactions between the circadian and stress systems can go awry. This mini-review is a useful reference to researchers studying basic neuroscience questions on these systems and how these systems are disrupted in psychiatric disorders. The review highlights the importance of recognizing the potential interactions between these systems in both normal and pathological conditions.

Competing Interests: No competing interests were disclosed.

We confirm that we have read this submission and believe that we have an appropriate level of expertise to confirm that it is of an acceptable scientific standard. 
The benefits of publishing with F1000Research:

- Your article is published within days, with no editorial bias

- You can publish traditional articles, null/negative results, case reports, data notes and more

- The peer review process is transparent and collaborative

- Your article is indexed in PubMed after passing peer review

- Dedicated customer support at every stage

For pre-submission enquiries, contact research@f1000.com 